\title{
Icebergs and iceberg rafted detritus (IRD) in the North Atlantic: facts and assumptions
}

\begin{abstract}
Over the last decade considerable attention has been given to evidence for the iceberg rafting of sediments into the North Atlantic, especially during Heinrich $(\mathrm{H})$ events (presumed to be associated with short-lived, abrupt intervals of increased iceberg and meltwater flux). However, our knowledge of the present sediment distribution within icebergs and the fate of this sediment during iceberg drift is rudimentary. Debris is usually concentrated in a 1-3 m laycr at the base of a glacier ; if present in calved icebergs, this layer is rapidly melted within a few 10 s to $100 \mathrm{~s}$ of $\mathrm{km}$ from an ice margin. Ice rafted debris (IRD) is frequently characterized by the weight percentage or counts of mineral grains within certain size fractions (i.e. $>63,>250 \mu \mathrm{m}$, etc.) with an implicit assumption that the selection of the size limits does not bias the data nor their interpretation. However, studies of glacial and glacial marine sediments indicate there is a poor correlation between the weight percentage in different sand-size classes, moreover, the bulk of glacially derived sediments are typically silts and clays $(<63 \mu \mathrm{m})$. In areas close to the probable sources of iceberg discharge during Heinrich events, the abrupt changes are poorly defined by the sand-size IRD fraction but are dramatically highlighted by the input of fine-grained $(<63 \mu \mathrm{m})$ detrital carbonate. During the last glaciation, abrupt changes in IRD concentrations (IRD spikes) appear to be an important feature of the mid-latitude belt of the North Atlantic, whereas at higher latitudes, such as areas of the Labrador and Nordic seas, IRD input was more continuous and individual H-events cannot be identified solely by their IRD signal.
\end{abstract}

\section{Introduction}

Over the past decade considerable interest and excitement has been sparked by the identification in North Atlantic sediments of discrete core intervals with high concentrations of IRD. IRD from open marine sediment cores is identified in the literature as mineral grains $>63 \mu \mathrm{m}$ (sand-size; although the size definition of IRD varies, e.g. Molnia, 1972; Ruddiman, 1977; Bond and Lotti, 1995).

Glacially transported sediments (striated clasts and far-travelled erratics) were first described in detail from marine sediments in the North Atlantic by Bramlette and Bradley (1940). Little came from these investigations until the 1970s (cf. Molnia, 1972) when downcore changes in IRD were computed as fluxes over intervals associated with Marine Isotope Stages 1 to 5 (approximately the last $130 \mathrm{ka}$ ) (Ruddiman, 1977). Subsequently, Heinrich (1988) systematically counted the numbers of lithic clasts and foraminifera in a series of cores west of Portugal, and showed that the percentages of lithics > $180 \mu \mathrm{m}$ in these cores represented a series of IRD events. These discrete events were later named "Heinrich" or H-events (Broecker et al., 1992) and interpreted as being the result of "armadas" of icebergs being suddenly released from the Laurentide Ice Sheet (Broecker, 1994; Dowdeswell et al., 1995; MacAyeal, 1993). Since the early 1990s numerous papers have described and interpreted evidence for H-events in the North Atlantic (e.g. Hillaire-Marcel et al., 1994; Keigwin and Lehman, 1994; Hemming et al., 1998; for review see Andrews, 1998). $\mathrm{H}$ events have durations of a few hundred to 1000 years and recurrence intervals of approximately 7,000 years on average (Bond and Lotti, 1995).

The purpose of this review paper is to examine what we know about the present distribution of icebergs, the controls on the distribution of IRD into the oceans, the characteristics of sediments released from iceberg melting, and some issues that pertain to the interpretation of H-events. Warren (1992) noted that the interpretation of IRD records can be complex; however, the interest in millennial-scale climate change has emphasized the climatic interpretations of iceberg rafted sediment the expense of understanding the glaciological and sedimentological complexities (cf. Dowdeswell et al., 1999; Clarke et al., 1999).

This paper will focus on problems associated with the interpretation of changes in IRD concentrations and 


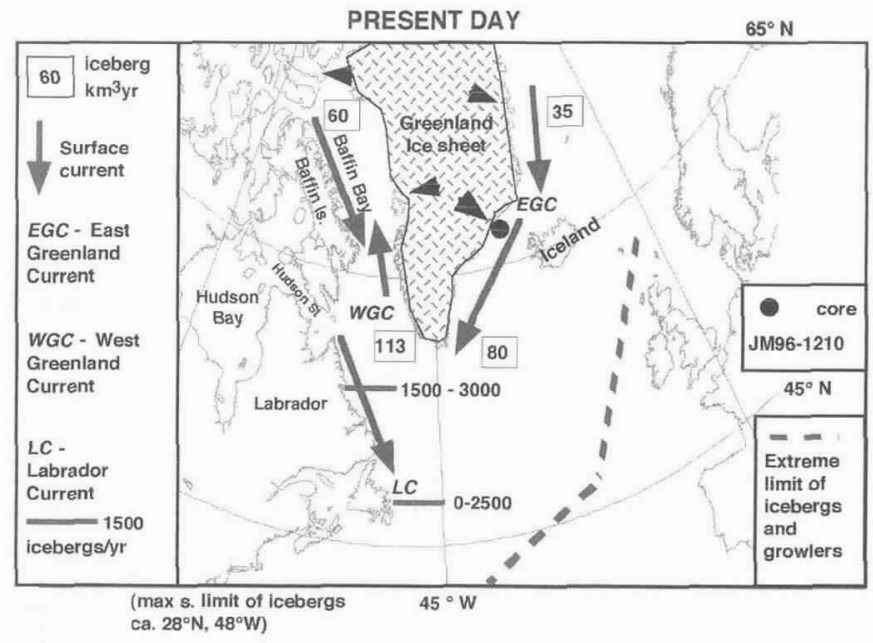

LAST GLACIAL PERIOD

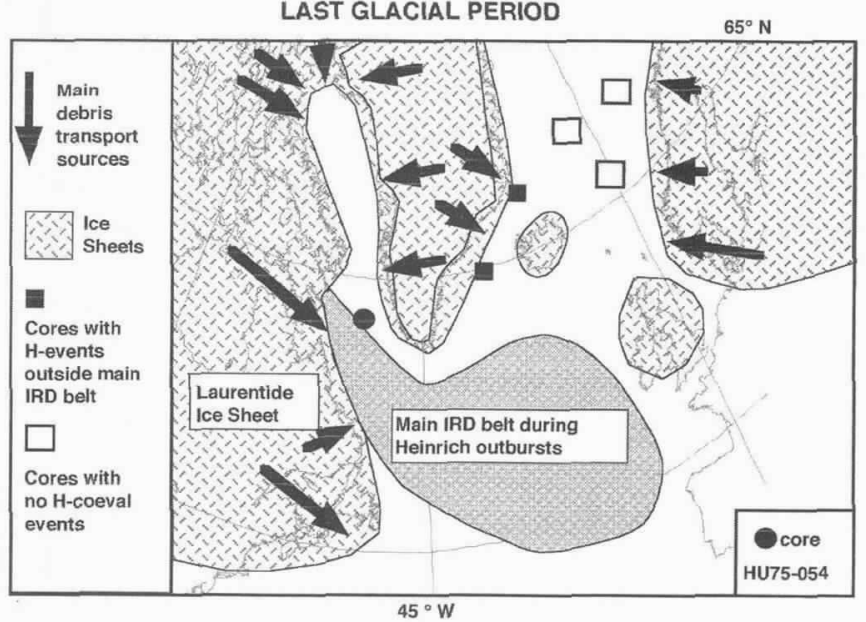

Figure 1. Upper: Map of the North Atlantic region showing the present volume of icebergs calved each year from Greenland (from Reeh, 1985), the fluxes along the Labrador/Newfoundland margin, and the maximum observed limits of iceberg drift (from International Ice Patrol). The present day extent of the Greenland Ice Sheet is shown schematically.

Lower: Ice sheet extent around the North Atlantic during the last glacial maximum, showing the major sources for icebergs, IRD belt, and cores with and without coeval Heinrich events (e.g. Dowdeswell et al., 1999). The extent of the ice sheets is shown schematically.

their relationship to iceberg discharge. The four major issues that need to be addressed are: 1) what is the past and present volume of icebergs calved into the North Atlantic; 2) what is the probable distribution of sediments within these icebergs; 3 ) what are the controls on the trajectory and melt histories of icebergs; and 4) what are the characteristics of iceberg transported sediments? The major source of data and ideas for this review is the information provided by the International Ice Patrol in their web site (www.uscg.mil/lantarea/iip/home.html), a series of reports from the Scott Polar Institute, University of Cambridge (e.g. Macqueen, 1991), and the numerous core studies reported in the literature (Andrews and Matsch, 1983).

\section{Modern iceberg distribution}

In the northern North Atlantic the major source for icebergs is the calving of outlet glaciers from the Greenland Ice Sheet. A relatively small additional source is the glaciers of the Canadian Arctic Archipelago. Reeh (1985) has estimated the flux of icebergs at $310 \mathrm{~km} 3 / \mathrm{yr}$ from various glaciers and sectors of the Greenland Ice Sheet, based upon the ice sheet's mass balance (Figure 1). Most icebergs are released from outlet glaciers of the Greenland Ice Sheet and their rate and direction of drift is determined by the surface currents. The main currents responsible for bringing icebergs into the mid-latitude North Atlantic are the Labrador Current (Greenland and Canadian icebergs), and the East Iceland Current (East Greenland). The International Ice Patrol has published a map showing the historic maximum limits of icebergs in the North Atlantic (Figure 1). It would be naïve to associate this limit with the extent of IRD sediment unless there is explicit information that all icebergs retain measurable sediment concentrations along their entire transport route.

\section{Sediment distribution in outlet glaciers}

The melting and destruction of icebergs releases freshwater to the oceans. However, the quantity and pattern of sediment release is controlled by the distribution of sediment within an iceberg, which in turn relates to the patterns of sediments within glaciers and ice sheets, and by the disintegration history of each iceberg. The main control on sediment distribution within glacier ice depends on the basal thermal regime of the ice mass (Boulton, 1972; Dreimanis, 1976; Drewry, 1986; Alley and MacAyeal, 1994).

There are two primary sources of sediment for glaciers and ice sheets; the first is from the subaerial weathering of exposed cliffs and nunataks that project above glacier surfaces, and the second is from erosion at the base of the ice. Material that falls onto the ice surface, depending upon whether this happens above or below the Equilibrium Line Altitude (ELA) of the ice sheet, is transported in three distinct positions (Figure 2 ). The first is as supraglacial debris, the second is englacial, and the third is basal debris. This first source of sediment is, however, rather restricted and at the continental scale will only make up a small fraction of the total sediment load.

However, for large ice sheets which completely cover all outcrops, the major source of sediment is from the erosion and transport of bedrock at their base. However, this will only produce a debris-charged basal unit if the glacier is at the pressure melting point, and the thickness of this basal unit is generally limited to 1 to a few meters (Drewry, 1986). Measurements of sediment concentrations in glaciers frequently indicate a basal, sediment-rich layer 1-3 m thick with virtually debris-clear ice above (e.g. Dowdeswell, 1986).

In my experience thick sequences of subglacial and englacial sediment within a glacier's margins are rare for Canadian or Greenland calving fronts. However, thick sequences might be produced at the margins of subpolar 


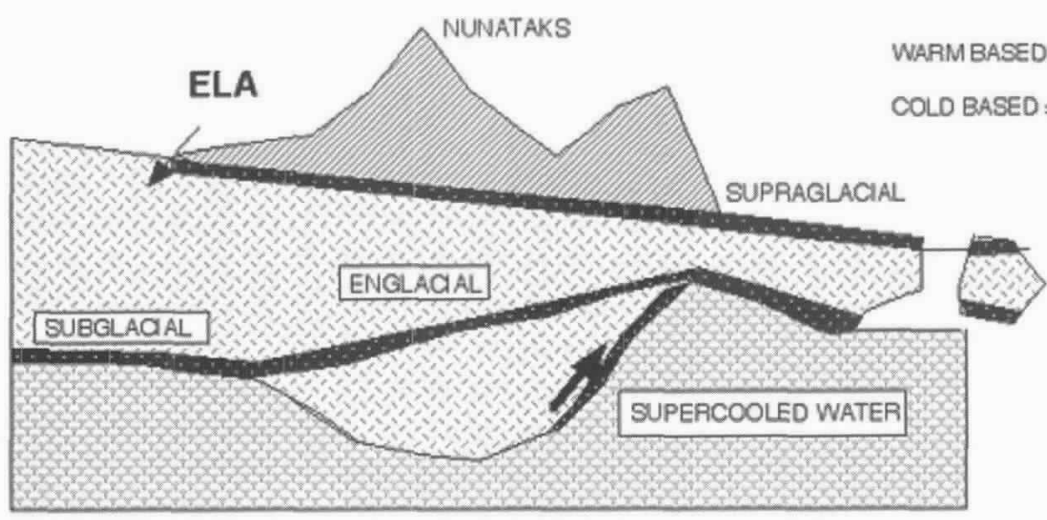

WARMBASEO
COLD BASED

WARM BASED
Figure 2. Schematic distribution of an ice stream moving to the open ocean through an area such as Hudson Strait showing the location of supraglacial, englacial, and subglacial debris. In fast-flowing outlets most debris is located in the lowermost 1-3 m of ice. The Equilibrium Line Altitude (ELA) on a glacier divides the accumulation zone from the lower ablation zone. Debris which falls onto the glacier in the ablation zone remains on the surface. glaciers, possibly due to a change in basal thermal conditions over time from cold-based to warm-based (Boulton, 1972; Drewry, 1986; MacAyeal, 1993) (Figure 2 ), or as recently suggested, by the freezing-on of finegrained sediments entrained in supercooled water rising toward a glacier margin (Lawson et al., 1998).

Ice with debris distributed through a substantial vertical thickness is required to maintain the IRD rain-out over the required late glacial drift trajectory of icebergs during Heinrich events (Figure 1). Thus we may have a "no analog" situation where modern tidewater ice fronts do not fully represent paleo-conditions.

The calving process differs between two end members. In the fast-flowing, maritime temperate areas of Southwest Alaska, large numbers of relatively small icebergs are calved from vertical ice cliffs. In contrast, in Antarctica the outlets extend seaward as ice shelves and calving results in the production of large tabular bergs, and the rate of iceberg production (icebergs/yr) is low. In Greenland the icebergs are substantially bigger than those produced in Alaska but are rarely tabular. In the Greenland tidewater environment, ice extends seaward as a ramp (an incipient ice shelf) but annual calving restricts the seaward extension. Neither Alaskan nor Antarctic icebergs carry much sediment (Drewry, 1986) and the amount of debris carried in Greenland icebergs (or others for that matter) is essentially unknown (unsampled), although some estimates have been made (Syvitski et al., 1996) based on glaciological observations.

Thus our knowledge of the present day distribution of sediment in glaciers and ice sheets indicates that it constitutes an extremely small fraction of the total volume of ice that is calved, and it is moreover, concentrated in a thin basal unit. It is worth noting that most observations of Greenland and Canadian icebergs by the International Iceberg Patrol indicate that they are "clean" (person. commun. 1999).

\section{Rates of iceberg melting and iceberg fluxes}

Although the information on the total volume of icebergs released into the North Atlantic from Greenland is important, from a paleoceanographic perspective what is more critical is the flux of icebergs at certain transects. Because of the intense oil exploration in Baffin Bay and the Labrador Sea in the 1970s data were collected, albeit for a limited period. In addition, the International Ice Patrol provides valuable information on the numbers of icebergs off Newfoundland. Information on iceberg size has been extracted from shipboard measurements and aircraft observations.

In terms of iceberg transport of both freshwater and sediment there are three important considerations; 1 ) how quickly do the icebergs track from the ice margin into the fjords and onto the shelf; 2) what is their transport route once they have reached the "open ocean," and; 3) what is the rate of melting and mechanical destruction?

The release of sediment from the base or within an iceberg depends on the distribution of sediment within an iceberg (see above) and the rate of melting. However, the amount of sediment that is available for deposition outside a fiord or at the inner shelf depends on the time when an iceberg is calved, and the rate at which it can leave the marginal zone of the glacier. In the northern North Atlantic landfast sea-ice forms an impediment to transport of icebergs for approximately 9 months of the year. Depending on the local oceanography (e.g. Syvitski et al., 1996) much of the sediment may be melted during such periods. Moreover, many East Greenland outlets end in "sikussaks" (Syvitski et al., 1996) which are a bathymetrically confined complex of icebergs, bergy bits, and sea-ice which form a dense mélange and impede the seaward movement of icebergs. In Kangerlugssuaq Fjord, East Greenland (see JM96-1210, Figure 1) $15 \mathrm{~km}^{3}$ of ice per year is calved. The icebergs suffer considerable mass loss, including the sediment load, within the sikussak (Syvitski et al., 1996) because the transport of freshwater seaward is balanced by warm $\left(1-2^{\circ} \mathrm{C}\right)$ Arctic Intermediate Water being brought in below $200 \mathrm{~m}$ water depth to the calving ice front. Because it is estimated to take 1-3 years to traverse the sikussak it is estimated that most glacial sediment is deposited near the outlet's terminus (Syvitksi et al., 1996). 
Once icebergs pass the outer coastline, their drift rates and directions are largely controlled by the water movement between the surface and the keel depth. In the northern North Atlantic most icebergs from Greenland would track into "southern" latitudes via the East Greenland Current and the Labrador Current (Figure 1). The Coriolis force would deflect the icebergs toward the land, rather than directing them past the shelf break across the adjacent deep sea basins (Matsumoto, 1996). However, during periods of maximum ice sheet advance, when ice was grounded at the shelf break, icebergs would be largely forced to track across the deepsea basins (e.g. Dowdeswell et al., 1995).

The rate of mass loss of icebergs has been the subject of several empirical studies, largely concerned with the need to forecast iceberg numbers in shipping lanes and their effects on oil exploration platforms (Macqueen, 1991). Empirical models have been used by researchers in an attempt to reconstruct IRD histories for parts of the North Atlantic region (Matsumoto, 1996). For example, the estimated rate of melt with a water temperature of $0^{\circ} \mathrm{C}$ varies between 0.01 to $0.1 \mathrm{~m}$ per day (Dowdeswell and Murray, 1990) thus indicating that a 3 $m$ thick basal sediment-rich layer would be melted in a month to one year.

The critical factors which lead to the destruction of an iceberg are: below the waterline (Figure 3) -the relative velocity of the iceberg and the temperature difference between the ice and the surrounding seawater; above the waterline- the rate of melting is controlled by the air temperature, the fluxes of sensible and latent heat from the atmosphere, and net radiation. At the waterline itself the iceberg is eroded by wave action. The combination of these processes, acting over days and weeks, results in changes in the center of gravity of an iceberg, thus during their drift most icebergs will turn over. This statement does not apply to large tabular bergs nor to sea ice rafts. The effects of these processes (Figure 3) are to reduce both the volume and number of icebergs along a drift track. The sediment load within icebergs will decrease with time, and probably at a faster rate than the iceberg volume loss per se because of the restricted distribution of sediment within an iceberg (Figure 2). The changes in the flux of IRD from a source calving margin are poorly known; off East Greenland, for example, Andrews et al. (1997) showed that IRD dropped off from the ice sheet margin following a power function. Thus very little coarse IRD sediment reaches the mid-shelf area (approximately $68^{\circ} \mathrm{N}$ ) today.

The approximate number of icebergs released into the North Atlantic per year can be crudely estimated if we make an assumption about the average draft. Assuming that the average draft is $400 \mathrm{~m}$, and given a volume of approximately $300 \mathrm{~km}^{3}$ of ice, then the area covered by icebergs would be around $800 \mathrm{~km}^{2}$. If the icebergs are cubes $400 \times 400 \times 400 \mathrm{~m}$ then a figure of 5000 icebergs /yr is derived. However, actual estimates range from 15,000 to 30,000 because iceberg dimensions

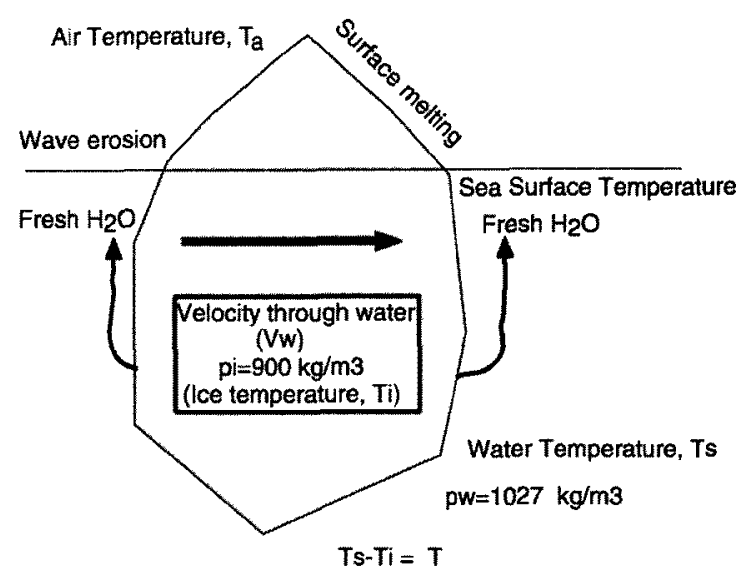

Iceberg melt rate, $M(\mathrm{~m} \mathrm{sec}-1)$

$$
\begin{aligned}
\text { 1) } M & =2.08 \times 10^{-7}(T s+1.8)^{1.5} \quad \text { (Russell-Head, 1980) } \\
\text { 2) } M=6.74 \times 10^{-6} \mathrm{Vw} w^{0.8} \mathrm{~T} / \mathrm{x}^{0.2} & \text { (Weeks and Cameron, 1973) } \\
p w & =\text { water density } \quad p i=i c e \text { density }
\end{aligned}
$$

Figure 3. Schematic dingram of the main variables intolved in simple models of iceberg decay (see references therein).

are on average less than those used above. However, there has been no systematic attempt to compute iceberg fluxes (i.e. number of icebergs/unit area/time, or number of icebergs crossing a marked transect = number/per unit length/time) except in the area east of Newfoundland at $48^{\circ} \mathrm{N}$. Estimates have been made for particular years stemming from the interest in oil exploration along the northeastern margin of Canada particularly in the 1970's. Much of this information is in the gray literature and not readily available. A study of the number of icebergs per $1000 \mathrm{~km}^{2}$ (1963-1972) in Baffin Bay indicates that number varies from a high of 15-60 per $1000 \mathrm{~km} 2$ in the extreme north of Baffin Bay to between 0 and 2 per $1000 \mathrm{~km}^{2}$ off Hudson Strait. Thus the decrease in numbers along the drift route falls off rapidly over a distance of approximately $1500-2000 \mathrm{~km}$. Miller and Hotzel (1984) estimated the number of icebergs crossing a series of transects on the Labrador Shelf, and arrived at yearly estimates of $\sim 6-15$ icebergs $\mathrm{km}-1$ per year. Iceberg numbers decreased from west to east, being in the range of 25-35 over the marginal trough to 5-9 over the slope. The total numbers of icebergs crossing these transects varied from 1400 to 3000 icebergs/year. Farther south, the International Ice Patrol's count of icebergs crossing $48^{\circ} \mathrm{N}$ exhibits a strong quasi-decadal cycle which has been linked to the North Atlantic Oscillation. For example, in 1999 no icebergs were reported in the waters off Newfoundland in June; this can be compared with an average of 480 and a maximum of 2200 icebergs in 1984.

From the sedimentological and paleoceanographic viewpoint, the key question is what is the probability of an iceberg crossing some small unit of the sea floor, typically $<100 \mathrm{~cm}^{2}$, and moreover melting some fraction of its mass which contains sediment. The above fluxes indicate 
a strong probability of an iceberg traversing an element of the sea floor (6-15 icebergs $\mathrm{km}^{-1}$ /year) but the difficult question is the probability of sediment deposition. This will depend very strongly on the distribution of debris within an iceberg, and the rate of iceberg destruction. However, there must be a significant random element in the release and deposition of glacially derived sediment, especially toward the distribution limits of icebergs, such that occasionally "spikes" of IRD must be interpreted with some caution in terms of paleoglaciology/paleoclimatology. However, the widespread occurrence of IRD sediments in $\mathrm{H}$-events indicates that at times iceberg rafting was a spatially pervasive process.

\section{Grain-size of glacial sediments and associated IRD problems}

The next question is how we recognize sediment, derived from glacial erosion, in marine sediments. The presence of sand-size (> $63 \mu \mathrm{m})$ minerogenic particles in Late Cenozoic high latitude marine cores is usually attributed to the rafting of glacially derived sediments in icebergs. However, sediment could also be transport-

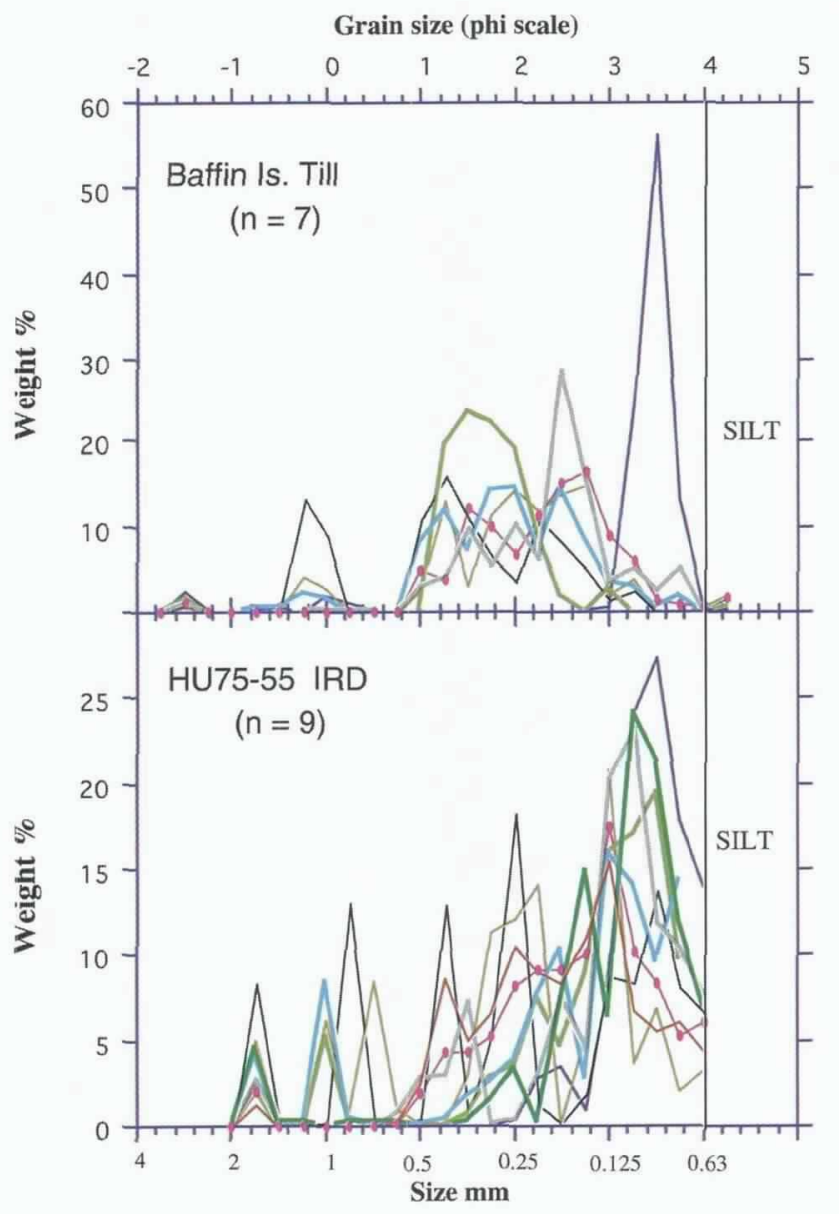

Figure 4. Distribution of sand-size particles from tills on Baffin Island, NE Canada, and from IRD intervals in core HU75-055 from the Labrador Sea. Each line represents a different sample from the two environments. Notice that in this presentation the sand fraction is computed as summing to 100\%. Data based on Settling Tube results at 1/4 phi intervals (Syvitski ed., 1991). ed on sea ice; for example, this is probably a major reason for the widespread distribution of sand-size Icelandic volcanic shards across the North Atlantic (cf. Bond and Lotti, 1995). They were probably derived from the fallout of wind born volcanics onto sea ice which was then carried to the Labrador Sea by the prevailing surface currents (Figure 1 ).

A small but important issue is that the measurements of particle size involve several different procedures and instruments, all with their strengths and weaknesses [Syvitski, 1991 \#4702]. Thus small differences in results may reflect different grain-size measurements, in addition, there have been few if any studies looking at the lateral variabilty of IRD on scales of centimeters and meters.

Studies of sediments deposited at the base of glaciers and ice sheets, so-called basal tills, are characterized by a bimodal size (weight percentage) distribution. The result of glacial abrasion is the production of large quantities of silt and clay-size particles, whereas the plucking of bedrock leads to large particles in the $\mathrm{cm}$ to $\mathrm{m}$ ranges (Drewry, 1986). Material in the sand-size, 2000 to $63 \mu \mathrm{m}$, is the least represented size fraction in typical glacial sediments (Dreimanis, 1976; Drewry, 1986), but the resulting size-spectra depend upon the mineralogy, which Slatt and Eyles (1981) describe as intercrystalline and intracrystalline, and relative rock weakness. The process of producing sand-size fragments at the base of an ice sheet is not well known (see Drewry, 1986, p. 114119 ) and their is some argument (Slatt and Eyles, 1981) as to whether the size is dependent upon crystal configuration or not. Thus, the attention given to the sandfraction in studies of abrupt changes in ice sheet/ocean interactions is largely because it represents an operationally simple parameter to define and measure, not because the processes are well understood! In addition, silt and clays can be transported to marine sites by other processes, such as wind, meltwater plumes, resuspension by bottom currents, or iceberg ploughing.

An article of faith in IRD studies is that there is a correlation in the abundance between the different sandsize fractions (Ruddiman, 1977); thus it is implicitly believed that a downcore plot of, say, the $>500 \mu \mathrm{m}$ fraction would result in the same pattern as a plot of the $>$ $63 \mu \mathrm{m}$ fraction (or some other fraction). This implication requires that the sand-fraction be distributed in such a way that variations in the weight percentage of the different size fractions are highly correlated.

This assumption is probably not correct and the problems with this hypothesis are illustrated in Figures 4 and 5 . Note that sedimentologist frequently illustrate grainsize distributions by either expressing the axis as the $\log 10$ of the particle diameter, or by using the phi notion $(\phi)$ where this is $\phi=-\log _{2} \mathrm{~mm}$. Our studies of the various sand-size distributions in Baffin Island tills (Figure 4; cf. Andrews, 1985) indicates that there is not a smooth distribution, rather the distribution of the different sandsize fractions is multi-modal; a similar distribution occurs in the sand-size IRD fraction from core HU75-055 

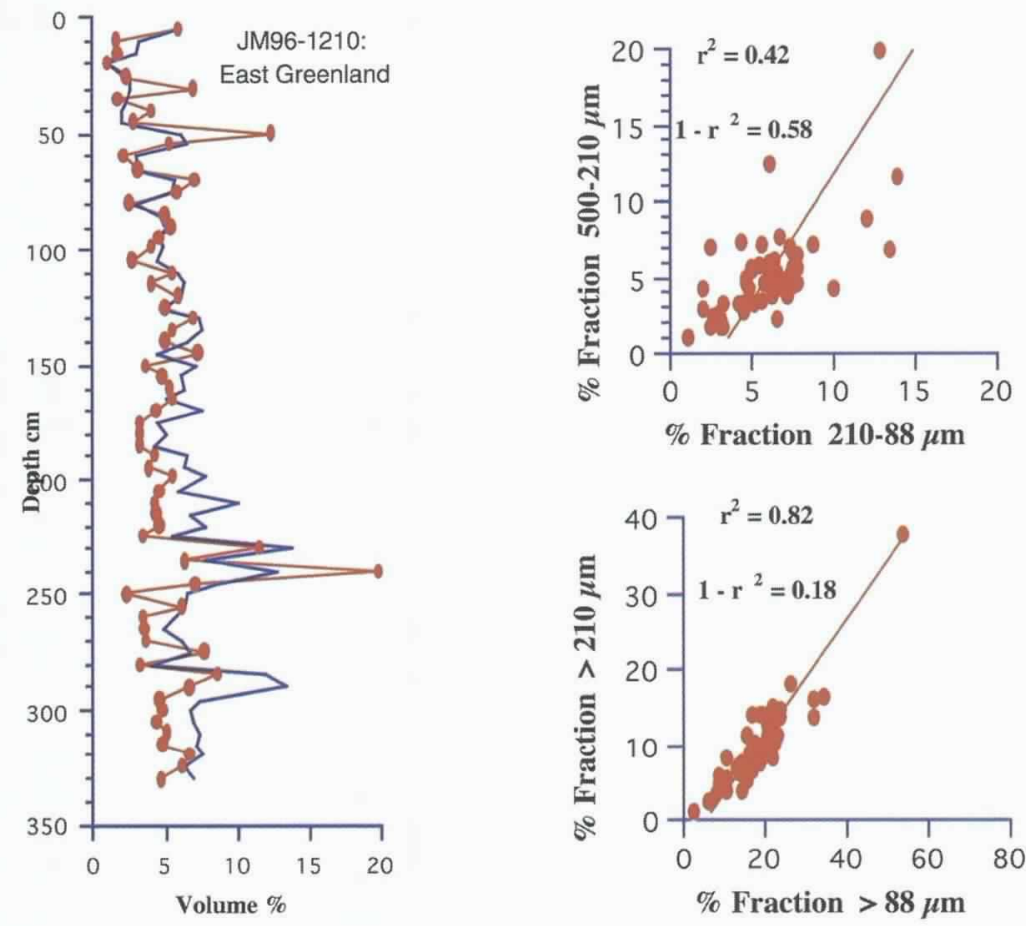

Figure 5. Downcore distribution of two sand-size fractions from core JM96-1210 off East Greenland (Figure 1 upper), showing some apparent correlation between the peaks of the two fractions. Scattergrams and correlation coefficients, $r$, for the fractions 500-210 $\mu \mathrm{m}$ versus 210-88 $\mu \mathrm{m}$ show correlation but the unexplained variance is still $>50 \%$. The correlation between the $>500 \mu \mathrm{m}$ fraction versus the $>105 \mu \mathrm{m}$ is much higher but the $r$ value is not a statistically valid measure of this agreement.

in the Labrador Sea (Figure 4). This lack of correspondence between the size-fractions is further illustrated in Figure 5, which is from a core off East Greenland within $10 \mathrm{~km}$ of a major calving glacier. The plot of the downcore variations in two sand-size fractions (500-210 and 210-88 $\mu \mathrm{m}$ ) indicates limited correlation with an unexplained variance of $58 \%$. However, a scatterplot of two more restricted fractions (500-595 $\mu \mathrm{m}$ versus 105-125 $\mu \mathrm{m}$ ) indicates an explained variance of only $10 \%$ $(\mathrm{r}=0.32)$. However, even this is misleading as much of this "explanation" is driven by a single extreme point (without that one data point the correlation is $\sim 0$ ). If the $>210$ and $>88 \mu \mathrm{m}$ are plotted (Figure 5), correlations would perforce be higher because these are cumulative percentages. In this case, however, the normal test of statistical significance would not be appropriate as cumulative data do not meet the test of independence.

The focus by many deep-sea researchers on the icerafted sand fraction is understandable as these grains are easily recognized. But this should not blind us to the fact that the sand fraction is usually a relatively small percentage of the total sediment. For example, Figure 6 illustrates the grain-size spectra of the sediment $<4 \mathrm{~mm}$ in diameter from JM96-1210 (Figures 1 and 5) off East Greenland. The grain-size distributions are multimodal with peaks in the very coarse and medium sand, and coarse and medium silt, but clearly the greatest volume of sediment is in the silt and clay-size fractions. Thus there is some validity in the argument that provenance studies based on the $<63 \mu \mathrm{m}$ fraction (silt and clay, Figure 6) are most representative of sediment source (cf. Hemming et al., 1998; Grousset et al., 1993). The fraction $<0.1 \mu \mathrm{m}$ is composed of clay-minerals (smectite, kaolinite), and finely ground mineral particles (quartz, feldspars, etc.) that have reached their "terminal grade" (Drewry, 1986, p. 116-117). Figure 6B illustrates the significant clay-size fraction of finely comminuted minerals off East Greenland. The high levels of clay minerals, mainly smectite are derived from weathering of the local Tertiary basalts, which overlie Precambrian shield rocks.

An alternative way of viewing IRD concentrations in marine sediments is to count, on $\mathrm{X}$-radiographs, visible particles $>2 \mathrm{~mm}$ over a specified depth interval (usually 2 cm) (e.g. Stein et al., 1996). Application of this method to cores in the Labrador Sea (Figure 1) illustrates problems in the identification of Heinrich (H-) events-they do not appear as well-defined and isolated IRD spikes (Figure 7). Although H- events are poorly defined by IRD, H-2 is explicitly captured by massive changes in the detrital carbonate content (Figure 7). Thus the record from HU75-054 indicates varying IRD concentrations but no simple pattern of abrupt $\mathrm{H}$ events. The lack of parallelism between the counted IRD, from X-radiography, and the weight percentage $>2$ $\mathrm{mm}$ indicates the problem of adequately sampling IRD by extraction of a small representative "plug" of sediment. A message from this analysis is that in the more ice-proximal ocean basins, such as the Labrador and Nordic seas, the IRD patterns are not in themselves diagnostic of H-events (Dowdeswell et al., 1999), and the release of sediment from icebergs was a pervasive process at sites near ice sheet margins during periods of glaciation.

At some sites in the North Atlantic an argument can be made that during $\mathrm{H}$-events there is relatively little change in the IRD (lithic) flux but there is a dramatic reduction in foraminifera numbers (= barren zones). This could be explained by either a dilution due to a rapid pulse of sediment (Thomson et al., 1995) or by a real reduction in foraminifera, possibly associated with an extensive "fresh" meltwater cap. The meltwater might be caused by the melting of a massive discharge of icebergs (Broecker, 1994), or it might be caused by an outbreak of freshwater, ponded at the base of the Laurentide Ice Sheet (Dowdeswell and Siegert, 1999) and exiting through Hudson Strait as hypothesized by Shoemaker (1992). The character of H-deposits off Hudson Strait (Hesse and Khodabakhsh, 1998) are sed- 

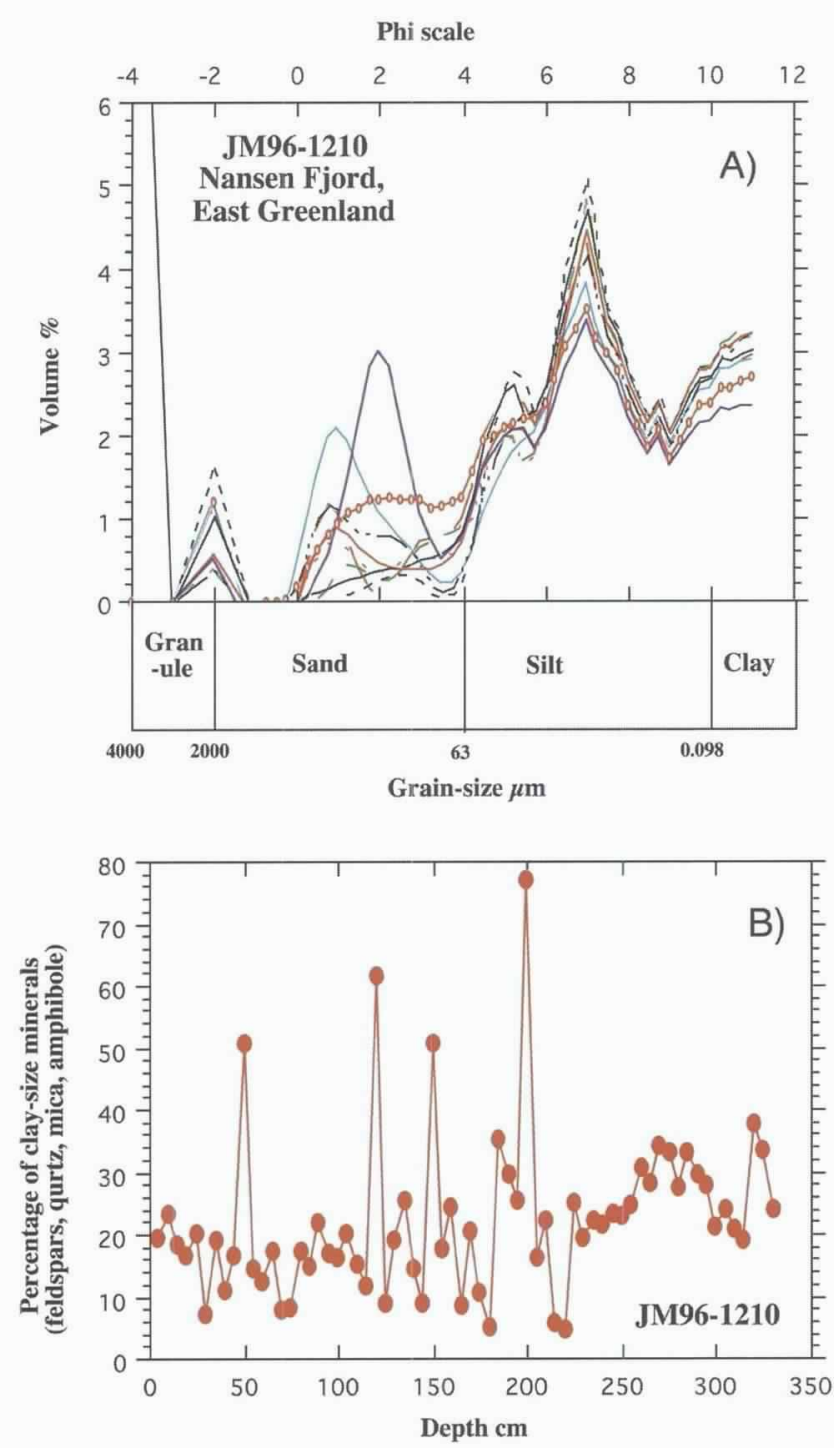

Figure 6. Plot of the grain-size spectra between -4 and $11 \phi(4000-<0.98$ $\mu \mathrm{m})$ for samples from JM96-1210, off Nansen Fjord, East Greenland. Note the multi-modal nature of the distributions.

imentologically much more complex than an IRD rainout of sand-size particles. H-sediments include massive deposits of fine grained silts and clays, but it is not clear whether the principal source of these fine-grained sediments are icebergs or suspended sediment plumes.

\section{Conclusions}

If the present is the key to the past then the study of IRD variations in North Atlantic sediments has proceeded with little knowledge about the characteristics of sediment released along the iceberg transport paths followed by modern icebergs (Figure 1). Although the observed maximum limits of icebergs extends well south of the iceberg calving areas it cannot be assumed that these far travelled icebergs contained sediment, in fact it is unlikely that they contained more than a few grains per $\mathrm{m}^{3}$ of ice. Moreover, there is evidence that the release of IRD into the Nordic Seas was more chaotic (Dowdeswell et al., 1999) than the pattern observed in the IRD belt of the North Atlantic (Ruddiman, 1977; Bond and Lotti, 1995). To ensure that changes in the IRD content of sediments is not the result of random sediment delivery then the fluxes $\left(\mathrm{g} / \mathrm{cm}^{2} /\right.$ unit time) should be calculated (Ruddiman, 1977). However the critical estimate, the rate of sediment accumulation during an $\mathrm{H}$-event, is not known better than a factor of about 5 (250 versus 1250 years), nor are there many detailed analyses of changes in sediment density, hence the flux calculation has some problems. But, as an example, Keigwin and Lehman (1994) estimated a flux of sand at $\sim 5 \mathrm{~g} / \mathrm{cm}^{2} / \mathrm{ky}$ during H-1 at a distal site in the North Atlantic. This value can be compared with late Holocene values of between 1 and $5 \mathrm{~g} / \mathrm{cm}^{2} / \mathrm{ky}$ along the inner shelf of East Greenland, seaward of the JM961210 site (Figure 1; Andrews et al., 1997), and close to active calving outlet glaciers. Maximum values within the outer fjords in this area reached values of $>1000$ $\mathrm{g} / \mathrm{cm}^{2} / \mathrm{ky}$ of the sand fraction.

It is necessary to bear in mind that a change in IRD flux could be due to three different scenarios: 1) an increase in the iceberg flux with sediment content and melt rate held constant; 2) or a change in sediment

\section{HU75-054 Labrador Sea}

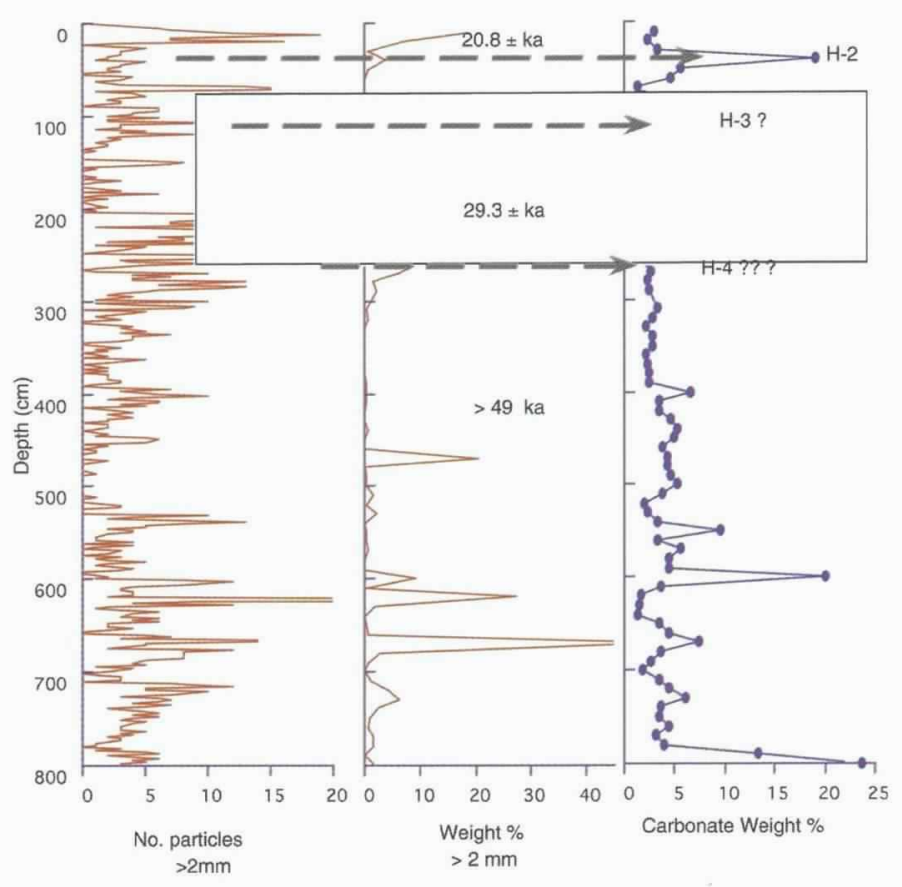

Figure 7. Comparison of different data from core HU75-054 in northern Labrador Sea showing the changes in numbers of grains $>2 \mathrm{~mm}$ as counted every $2 \mathrm{~cm}$ from X-radiographs (volume approximately $28 \mathrm{~cm}^{3}$, weight of material $>2 \mathrm{~mm}$ from particle size analyses (sampled from a ring with a volume of $10.4 \mathrm{ml}$ ), and the weight \% of detrital carbonate. Note the difficulty in defining $H$-events when the larger lithics are counted versus the weight percentage approach (middle column). 
concentration, with the iceberg flux remaining steady and the rate of melt not varying, or finally; 3 ) a change in the locus of the main zone of iceberg melting, due to changes in surface and subsurface temperature conditions. It has been argued that the sediment concentrations of icebergs would change during an H-event (Alley and MacAyeal, 1994), and the isolation of a specific sediment provenance by isotopic fingerprinting (Hemming et al., 1998) is a valuable tool in identifying abrupt changes in the sediment record.

The "pure" climatic interpretation of IRD events is not without glaciological alternatives (e.g. Clarke et al., 1999) and it is a mistake to consider all IRD records as being in the mode of $\mathrm{H}$-events. Data from the Labrador Sea (Figure 6), and off East Greenland (Figure 5) indicate that in some regions IRD is a pervasive not a punctuated signal. It is also obvious (Figure 6, middle column) that the bulk of sediment transported away from ice sheet margins is primarily in the silt and claysize fractions and that a variety of processes, other than IRD, contribute sediments to the ice distal continental slopes and deep-sea basins (Hesse and Khodabakhsh, 1998).

Thus although abrupt changes in the IRD content of marine cores in the North Atlantic have led to considerable excitement in the paleoceanographic and glaciological communities, this must be tempered by an appreciation of the problems in understanding the "true" meaning of an IRD event. At the moment we fail the essential geological test of predicting the past from an understanding of present day processes. Although the connection between H-events, IRD, and massive glaciological collapse of the Laurentide (and other?) ice sheets is well demonstrated a predictive model of the processes involved still needs to be developed, although significant process is being made (Clarke et al., 1999; Dowdeswell and Siegert, 1999a).

\section{Acknowledgements}

I would like to thank The Oceanography Society for inviting me to speak on this topic at the 1999 Reno meeting. Support for my research over the last several years has been provided by grants from the National Science Foundation, especially from the Office of Polar programs. I wish to thank James Syvitski, Lloyd Keigwin, Kathy Licht, Donny Barber for internal reviews and Drs. Sidney Hemming and J. Stravers for reading and commenting on this contribution.

\section{REFERENCES}

Alley, R.B. and D.R. MacAyeal, 1994: Ice-rafted debris associated with binge-purge oscillations of the Laurentide Ice Sheet. Paleoceanography, 9, 503-511.

Andrews, J.T., 1985: Grain-size characteristics of Quaternary sediments, Baffin Island region. In: Quaternary Environments: Eastern Canadian Arctic, Baffin Bay, and Western Greenland. Andrews, J.T., ed.,
Boston, Allen and Unwin, 125-153.

Andrews, J.T. and C.L. Matsch, 1983: Glacial marine sediments and sedimentation: An annotated bibliography. Norwich, UK, Geo Abstracts Ltd., 227 pp.

Andrews, J.T., L.M. Smith, R. Preston, T. Cooper and A.E. Jennings, 1997: Spatial and temporal patterns of iceberg rafting debris (IRD) along the East Greenland margin, approximately. $68^{\circ} \mathrm{N}$, over the last $14 \mathrm{ka}$. Joumal of Quaternary Science, 12,1-13.

Andrews, J.T., 1998: Abrupt changes (Heinrich events) in late Quaternary North Atlantic marine envrionments: a history and review of data and concepts. Joumal of Quaternary Science, 13, 3-16.

Bond, G.C. and R. Lotti, 1995: Iceberg discharges into the North Atlantic on millennial time Scales During the Last Glaciation. Science, 267, 1005-1009.

Boulton, G.S., 1972: The role of thermal regime in glacial sedimentation. Inst. Br. Geogr. Special Publ., Special Publication No. 4, 1-19.

Bramlette, M.N. and W.H. Bradley, 1940: Geology and biology of north Atlantic deep-sea cores between Newfoundland and Ireland. Part I. Lithology and geological interpretations. United States Geological Survey, Professional Paper, 196-A, 1-34.

Broecker, W.S., 1994: Massive iceberg discharges as triggers for global climate change. Nature, 372, 421-424.

Broecker, W.S., G. Bond, J. McManus, M. Klas and E. Clark, 1992: Origin of the Northern Atlantic's Heinrich events. Climatic Dynamics, 6, 265-273.

Clarke, G.K.C., S.J. Marshall, C. Hillaire-Marcel, G. Bilodaeu and C. Veiga-Pires, 1999: A glaciological perspective on Heinrich events. In: Mechanisms of Global Climate Change at Millennial Time Scales. P.U. Clark, R.S. Webb and L. Keigwin, L. D., eds., Washington, DC, American Geophysical Union, 243262.

Dowdeswell, J.A., 1986: The Distribution and Character of Sediments in a Tidewater Glacier, Southern Baffin Island, N.W.T., Canada. Arctic and Alpine Research, 18, 45-46.

Dowdeswell, J.A. and T. Murray, 1990: Modelling rates of sedimentation from icebergs. In: Glacimarine Environments: Processes and Sediments. J.A. Dowdeswell and J.D. Scourse, eds., Geology Society Special Publication, 121-137.

Dowdeswell, J.A., M.A. Maslin, J.T. Andrews and I.N. McCave, 1995: Iceberg production, debris rafting, and the extent and thickness of Heinrich layers (H-1, H-2) in North Atlantic sediments. Geology, 23, 301-304.

Dowdeswell, J.A. and M.J. Siegert, 1999a: Ice-sheet numerical modeling and marine geophysical measurements of glacier-derived sedimentation on the Eurasion Arctic continental margins. Geological Society of America Bulletin, 111, 1080-1097.

Dowdeswell, J.A. and M.J. Siegert, M. J., 1999b: The dimensions and topographic setting of Antarctic subglacial lakes and implications for large-scale water 
storage beneath continental ice sheets. Gcological Society of America Bulletin, 111, 254-263.

Dowdeswell, J.A., A. Elverhoi, J.T. Andrews and D. Hebbeln, 1999: The production of ice-rafted (Heinrich) layers, ice-stream stability and large-scale glacial sedimentation in the North Atlantic and Nordic Seas. Nature, 400, 348-351.

Dreimanis, A., 1976: Tills: Their origin and properties. In: Glacial Till an Inter-disciplinary Study. R.F. Legget, ed., The Royal Society of Canada Special Publications, p. 11-49.

Drewry, D., 1986: Glacial Geologic Processes. London, Edward Arnold. 276 pp.

Grousset, F.E., L. Labeyrie, J.A. Sinko, M. Cremer, G. Bond, J. Duprat, E. Cortijo and S. Huon, 1993: Patterns of ice-rafted detritus in the glacial North Atlantic (40-55 N). Paleoceanography, 8, 175-192.

Heinrich, H., 1988: Origin and consequences of cyclic ice rafting in the Northeast Atlantic Ocean during the past 130,000 years. Quaternary Research 29, 143-152.

Hemming, S.R., W.S. Broecker, W.D. Sharp, G.C. Bond, R.H. Gwiadzda, J.F. McManus, M. Klas and I. Hajdas, 1998: Provenance of Heinrich layers in core V28-82, northeastern Atlantic: ${ }^{11} \mathrm{Ar} /{ }^{39} \mathrm{Ar}$ ages of ice-rafted hornblende, $\mathrm{Pb}$ isotopes in feldspar grains, and $\mathrm{Nd}$ $\mathrm{Sr}-\mathrm{Pb}$ isotopes in the fine sediment fraction. Earth and Planetray Science Letters, 164, 317-333.

Hesse, R. and S. Khodabakhsh, 1998: Depositional facies of late Pleistocene Heinrich events in the Labrador Sea. Geology, 26(2), 103-106.

Hillaire-Marcel, C., A. de Vernal, G. Bilodeau and G. Wu, 1994: Isotope stratigraphy, sedimentation rates, deep circulation, and carbonate events in the Labrador Sea during the last $200 \mathrm{kyr}$. Canadian Journal of Earth Sciences, 31, 63-89.

Keigwin, L.D. and S.J. Lehman, S. J., 1994: Deep circulation change linked to HEINRICH event 1 and Younger Dryas in a middepth North Atlantic core. Paleoceanography, 9, 185-194.

Lawson, D.E., J.C. Strasser, E.B. Evenson, R.B. Alley, G.J. Larson and S.A. Arcone, 1998: Glaciohydraulic supercooling: a freeze-on mechanism to create stratified, debris-rich basal ice: I. Field evidence. Journal of Glaciology, 44.

MacAyeal, D.R., 1993: Binge/purge oscillations of the Laurentide Ice Sheet as a cause of North Atlantic's Heinrich events. Paleoceunograplyy, 8, 775-784.

Macqueen, A.D. (compiler) 1991: Icebergs: a bibliography. Iceberg Research No. 16, Scott Polar Research Institute, Cambridge, UK, $51 \mathrm{pp}$.

Matsumoto, K., 1996: An iceberg drift and decay model to compute the ice-rafted debris and iceberg meltwa- ter flux: application to the interglacial North Atlantic. Paleoceanography, 11(6), 729-742.

Miller, J.D. and I.S. Hotzel, 1984: Iceberg flux estimation in the Labrador Sea. In: Procedings of the 3rd International Offshore Mechanics and Arctic Engineering Symposium, Vol. 3. V.J. Linardini, ed., New York Society of Mechanical Engineers, 298-304.

Molnia, B.F. 1972: Pleistocene ice rafting in the North Atlantic Ocean. Ph.D. thesis, University of South Carolina, Columbia, 103 pp.

Reeh, N., 1985: Greenland Ice-Sheet Mass Balance and Sea-Level Change. In: Glaciers, Ice Sheets, and Sea Level: Effect of a CO2 induced climatic change. Seattle, WA, United States Department of Energy, 155-171.

Ruddiman, W.F., 1977: Late Quaternary deposition of ice-rafted sand in the sub-polar North Atlantic (40-60 N). Geological Society of America Bulletin, 88, 1813-1827.

Russell-Head, D.D. 1980: The melting of free-drifting icebergs. Annals of Glaciology, 1, 119-122.

Shoemaker, E.M., 1992: Water sheet outburst floods from the Laurentide Ice Sheet. Canadian Journal of Earth Sciences, 29, 1250-1264.

Slatt, R.M. and N. Eyles, 1981: Petrology of glacial sand: implications for the origin and mechanical durability of lithic fragments. Sedimentology, 28, 171-183.

Stein, R., S.-I. Nam, H. Grobe, and H. Hubberten, 1996 : Late Quaternary glacial history and short-term icerafted debris fluctuations along the East Greenland continental margin. In: Late Quaternary paleoceanography of North Atlantic margins. J.T. Andrews, W.A. Austen, H. Bergsten and A.E. Jennings, eds., London Geological Society.

Syvitski, J.P.M., ed., 1991: Principles, methods, and application of particle size analysis. Cambridge University Press, 368pp.

Syvitski, J.P.M., J.T. Andrews and J.A. Dowdeswell, 1996: Sediment deposition in an iceberg-dominated glacimarine environment, East Greenland: basin fill implications. Global and Planetary Change, 12, 251-270.

Thomson, J., N.C. Higgs and T. Clayton, 1995: A geochemical criterion for the recognition of Heinrich events and estimation of their depositional fluxes by the ( ${ }^{23}$ Th $T$ excess) 0 profiling method. Earth and Planetary Science Letters, 135, 41-56.

Warren, C.R., 1992: Iceberg calving and the glacioclimatic record. Progress in Physical Geography, 16, 253-282.

Weeks, W.F. and W.J. Cameron, 1973: Icebergs as a fresh water source: an appraisal. Journal of Glaciology, 12, 207-233. 